\title{
Relationship Between Fatty Acid Concentrations in Wine Yeasts and Sugar Fermentation at Different Temperatures*
}

\author{
J.J. Venter ${ }^{1}$, H.J.J. van Vuuren ${ }^{2}$, A. Tromp ${ }^{1}$ and J.H. Randall ${ }^{3}$ \\ ${ }^{1}$ Viticultural and Oenological Research Institute (VORI), Private Bag X5026, 7600 Stellenbosch, ${ }^{2}$ Department of Microbiology and ${ }^{3}$ Department of \\ Biometry, University of Stellenbosch, 7600 Stellenbosch, Republic of South Africa. \\ Submitted for publication: April 1989 \\ Accepted for publication: August 1989 \\ Key words: Fatty acid, wine yeast, fermentation, temperature
}

\begin{abstract}
The effects of temperature and fermentation stage on the cellular concentrations of unsaturated and saturated fatty acids on the fermentation abilities of four different Saccharomyces cerevisiae wine yeasts were studied at three temperatures. The total unsaturated and saturated fatty acid concentrations were determined at six fermentation stages. Unsaturated fatty acid concentration decreased and the concentration of saturated fatty acids increased as fermentation proceeded. Saturated fatty acid concentration of the yeast cells correlated positively with high specific fermentation rates during the later stages of fermentation in contrast to the belief that fluid membranes with high unsaturated fatty acid concentrations enhance ethanol tolerance and, therefore, fermentation performance.
\end{abstract}

The cell membrane Saccharomyces cerevisiae encloses the cytoplasm and selectively allows nutrients to enter and metabolic products to leave the cell. Furthermore, cell wall components are deposited on this matrix during growth of the cell. It, therefore, affects growth and fermentation and is ultimately of interest to brewers and wine makers. Lipids are an integral part of cellular membranes and consequently changes in lipid composition are associated with changes in membrane characteristics such as fluidity and permeability (Rattray, Schibeci \& Kidby, 1975), which have been reported to affect ethanol tolerance of yeast (Thomas, Hossack \& Rose, 1978).

Factors which affect the lipid composition of micro-organisms are growth rate (Brown \& Rose, 1969a), medium composition (Brown \& Rose, 1969b), growth temperature (McMurrough \& Rose, 1971), dissolved-oxygen tension (Brown \& Rose, 1969a) and glucose concentration (Johnson, Nelson \& Brown, 1972). Lower growth temperatures for example increase the proportion of unsaturated lipids in yeast cells (Pfisterer, Hancock \& Garrison, 1977). However, according to McMurrough \& Rose (1971), temperature variation does not significantly alter the fatty acid composition of the early exponential phase cells, but profoundly affects the synthesis of these compounds during the later exponential phase. Because unsaturated fats melt at lower temperatures than their saturated counterparts, the change in composition related to growth temperatures has been described as an "antifreeze" effect; the increased proportion of unsaturated fats ensures a more fluid membrane structure at lower growth temperatures which presumably helps maintain membrane functions (Patel \& Lewis, 1982).

Fatty acids are structurally and functionally important and affect cell membrane function(s) to a great extent (Andreasen \& Stier, 1954). The nature of the fatty acids (incorporated into phospholipids) affects the functions of certain proteins in the membrane (Pfisterer et al., 1977). The functional role of lipids, their fatty acid composition and degree of unsaturation, are regarded as major factors in the transport effects of membranes and the realization of fermentative activities in micro-organisms (Sinensky, 1971). Unsaturated fatty acids (UFA) in yeasts and other eucaryotic organisms are produced by direct desaturation of a pre-existing saturated fatty acid by a desaturase system which requires molecular oxygen (Bloch et al., 1961). This desaturase enzyme system, however, becomes inactive when yeast cells grow in a medium containing unsaturated fatty acids (Radler, 1978).

This study was undertaken to determine the effects of temperature during fermentation on unsaturated and saturated fatty acid concentrations in four wine yeast strains and to establish whether there is a relationship between unsaturated or saturated fatty acid concentration and specific fermentation rate.

\section{MATERIALS AND METHODS}

Fermentations: The yeast strains, media and methods described by Venter et al. (1989) were used for the analyses and standardisation of yeast dry mass values to correspond with $12,25,50,75,100 \mathrm{~g} / \mathrm{l}$ and $125 \mathrm{~g} / \mathrm{l}$ sugar fermented (fermentation stages 1-6). Fermentation rates were previously determined by Venter et al. (1989) for the intervals 0-24, 13-37, 38$62,63-87,88-112 \mathrm{~g} / \mathrm{l}$ and $113-137 \mathrm{~g} / \mathrm{l}$ sugar fermented. These values were considered to indicate the activity of the yeasts at stages 1-6, respectively, and were used to determine specific fermentation rates (SFR) as $\mathrm{g} / \mathrm{l}$ sugar fermented/day/100 mg yeast cells. Mean saturation index ( $\mathrm{Sl}$ ) was also determined for all treatments using the following formula: SI $=\underline{\text { SFA }}$

UFA

Gas chromatographic analysis of fatty acids: The method of Moss, Shinoda \& Samuels (1982) was modified and used for fatty acid analysis. To $3 \mathrm{ml}$ yeast suspension ( 50 $\mathrm{mg}$ to $200 \mathrm{mg}$ yeast dry weight) in a $15 \mathrm{ml}$ glass bottle was added $4 \mathrm{ml}$ of methanol AR and $0,7 \mathrm{~g} \mathrm{NaOH}$, as well as 200

Acknowledgement: The authors wish to thank Professor M.A. Loos for a critical review of the manuscript

*Part of MSc. thesis presented at the University of Stellenbosch. Promotor: Prof. H.J.J. van Vuuren

\section{S. Afr. J. Enol. Vitic., Vol. 10 No. 21989}


$\mu \mathrm{l}$ of a $5 \mathrm{mg} / \mathrm{ml}$ solution of pentadecanoic acid (Sigma, St. Louis, USA) as internal standard. The suspension was flushed with nitrogen for 30 seconds to remove all oxygen and prevent peroxide formation. The bottle was sealed with a teflon-lined screw cap and placed in a boiling water bath for 1 hour. The saponified material was cooled for 15 minutes, and the $\mathrm{pH}$ adjusted to 2,0 by the addition of $4 \mathrm{ml} 6 \mathrm{MHCL}$. The free fatty acids were then methylated by the addition of $4 \mathrm{ml}$ of $14 \%$ boron trifluoride-methanol complex reagent (BDH Chemicals, LTD, Poole, England) and heated for 15 minutes in a water bath at $80-85^{\circ} \mathrm{C}$. The mixture was cooled to room temperature and methyl esters extracted by shaking with two successive $10 \mathrm{ml}$ portions of a 1:1 diethyl ether/hexane. The ether/ hexane layers were combined in a $50 \mathrm{ml}$ beaker and the volume was reduced to approximately $2 \mathrm{ml}$ under a gentle stream of nitrogen gas. The mixture was subsequently dried with $\mathrm{MgSO}_{4}$ and transferred to a Reacti-vial where the volume was further reduced to $0,1 \mathrm{ml}$. The final volume was either analysed by gaschromatograph (GC) or stored at $-20^{\circ} \mathrm{C}$ in a 2 $\mathrm{ml}$ screwcapped glass vial until analysis.

The fatty acid methyl esters in the samples were analysed on a Varian 3700 gas chromatograph equipped with a flame ionization detector, using a fused silica capillary column (50 $\mathrm{m} \times 0,3 \mathrm{~mm}$ I.D.) with OV-101 as stationary phase (HewlettPackard Corp., Avondale, Pa.). The injector temperature was maintained at $260^{\circ} \mathrm{C}$. Helium was used as carrier gas at a flow rate of $1,39 \mathrm{ml} / \mathrm{min}$. A $2 \mu \mathrm{l} \mathrm{sample} \mathrm{which} \mathrm{was} \mathrm{split} 50: 1$ to yield a $0,04 \mu \mathrm{l}$ sample on the column, was injected. The column temperature was controlled at $120^{\circ} \mathrm{C}$ for 3 minutes, then programmed at $5^{\circ} \mathrm{C} / \mathrm{min}$ to $260^{\circ} \mathrm{C}$, where it was maintained for 22 minutes before being cooled to the initial temperature for the next sample. The fatty acids from yeasts were identified by comparing the GC retention times of their methyl esters to those of authentic standards (Altech Associated Inc., Deerfield, USA). Peak areas were compared with that of the methyl ester of the pentadecanoic acid internal standard, and fatty acid concentrations determined by a Hewlett-Packard series laboratory system. The graphical method described by Venter et al. (1989) was used for the standardisation of unsaturated and saturated fatty acid concentrations to correspond with the concentrations of sugar fermented at fermentation stages 1 to 6.

Statistical analysis: A completely randomised experimental design was employed. Three measurements were taken at each of the six fermentation stages. Consequently an analysis, taking account of the potential correlations between measurements at the various stages, was performed. The analysis was performed using the REPEATED command of the SAS procedure GLM and the POLYNOMIAL transformation keyword for fermentation stages. The PRINTE option was used to perform a sphericity test, as described in the SAS User's Guide (Anon., 1985). Separate analyses were performed for unsaturated fatty acids, viz. $\mathrm{C} 14: 1+\mathrm{C} 16: 1+\mathrm{C} 18: 1$ and saturated fatty acids, viz. C8:0 + C10:0 + C12:0 + C14:0 $+\mathrm{C} 16: 0+\mathrm{C} 18: 0$ and fermentation rates (Venter et al., 1989). A standard VORI factorial statistical software package was used to test significant differences among treatment means (identical fermentation stages). The same program was used to determine correlation coefficients.

\section{RESULTS AND DISCUSSION}

For all three variables (UFA concentration, SFA concentration and fermentation rate) strain $\mathrm{x}$ temperature $\mathrm{x}$ stage interactions were indicated by the multivariate test (the sphericity test was rejected in all three cases) and separate analyses were therefore performed for each yeast strain. The approximate significance levels (SL) for UFA and SFA concentrations were respectively $0,7532,0,0018$ (WE 452), 0,5445, 0,2542 (WE 500), 0,5496, 0,1182 (WE 14), and 0,8492, 0,2509 (WE 372). In the UFA concentration analyses by strain, the sphericity tests were not rejected, but for the SFA concentration analyses, the sphericity test was rejected only in the case of WE 452.

In the case of fermentation rate only the WE 500 sphericity test was not rejected (SL $=0,1546)$. The analysis of fermentation rate by yeast strain showed stage $\mathrm{x}$ temperature (quadratic) interaction, although there was a general tendency suggesting that the nature of the interaction could be simplified to stage $\mathrm{x}$ temperature (linear). Venter et al. (1989) showed that each yeast strain had different fermentation rate patterns, with higher specific fermentation rates at the higher temperatures.

The rate of the decrease in UFA concentration (Fig. 1) and the variation in SFA concentration (Fig. 2) per $100 \mathrm{mg}$ cells from the first ( $12 \mathrm{~g} / \mathrm{l}$ sugar fermented) to the sixth stage (125 $\mathrm{g} / \mathrm{l}$ sugar fermented) differed significantly between temperatures for all four yeast stains (data not shown). The UFA and SFA contents of yeast cells are considered to be individual characteristics of strains as indicated by the temperature $\mathrm{x}$ strain $\mathrm{x}$ stage interaction.

The decline in the UFA concentration of the yeast cells as the fermentations progressed can be ascribed to growth of the cells under non-aerated conditions in the absence of exogenous sterols and unsaturated fatty acids (Venter et al., 1989). Occasional high values at advanced fermentation stages could be ascribed to experimental errors. The yeast dry mass increased considerably over the first three stages, but little or no yeast growth was observed over the final three stages (Venter et al., 1989). The larger decreases in UFA concentration with yeast strains WE 452 and WE 500 than with strains WE 14 and WE 372 from the first to the second fermentation stage (Fig. 1) were the result of their larger increases in dry mass during these stages. (Venter et al., 1989). The overall tendency of lower UFA concentrations at higher temperatures could therefore be ascribed to a corresponding higher growth rate of yeast cells, resulting in a dilution of UFA as these compounds are not produced under anaerobic conditions (Fig. 1).

Yeast strain WE 14 had the highest specific fermentation rates (SFR) at the first and second fermentation stages at $15^{\circ} \mathrm{C}$ and $20^{\circ} \mathrm{C}$, followed by WE 452 , WE 500 and WE 372 (Venter et al., 1989). However, at the sixth fermentation stage yeast strain WE 500 had the highest SFR of the four yeast strains at all three temperatures. The UFA concentrations showed a similar trend at $10^{\circ} \mathrm{C}$ with WE 500 being higher than WE 452 and WE 372 but at $15^{\circ} \mathrm{C}$ and $20^{\circ} \mathrm{C}$ no significant differences could be detected (Fig. $1 \&$ Table 1). At this (the sixth) stage SFR values of WE 452 and WE 500 tended to be higher than 

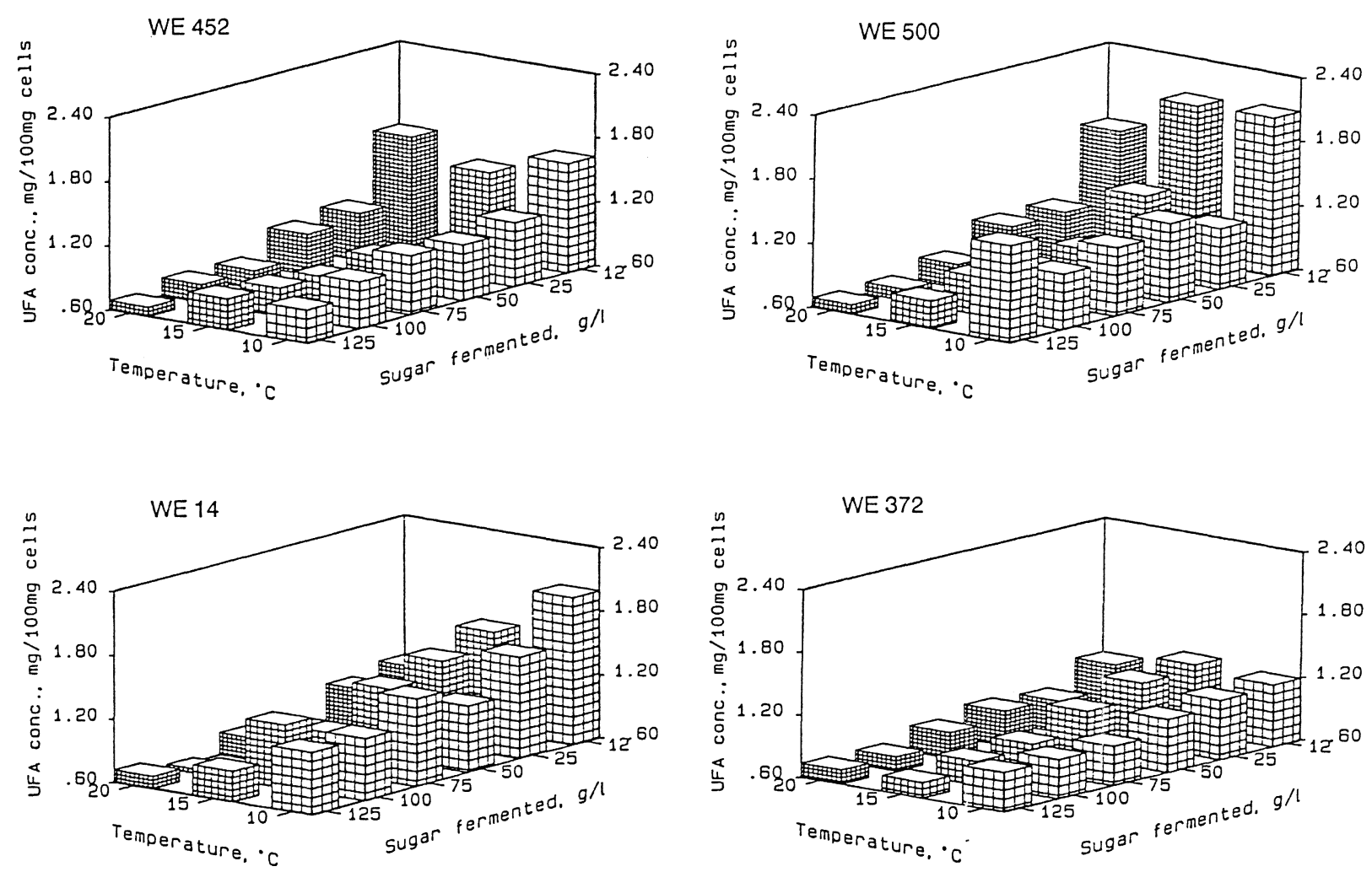

FIGURE 1

Unsaturated fatty acid concentration in cells of Saccharomyces cerevisiae strains WE 452, WE 500, WE 14 and WE 372 during fermentation at three temperatures.

that of WE 14 and WE 452 at $10^{\circ} \mathrm{C}$ and $15^{\circ} \mathrm{C}$, albeit not always significant (Table 2). However, at $20^{\circ} \mathrm{C}$ yeast strains WE 372 had the highest cell UFA concentrations (Fig. $1 \&$ Table 1), but the lowest SFR (Venter et al., 1989), whereas WE 452 and WE 500 had lower UFA concentrations with the highest SFR. Statistical analysis showed that a negative correlation $(r=-0,50)$ was found between the UFA concentration and the SFR during the sixth fermentation stage. Thus, a high UFA content alone does not ensure a high fermentation rate; it rather seems that a low UFA concentration correlates well with high SFR at $20^{\circ} \mathrm{C}$.

The SFA concentrations of strain WE 14 increased as the fermentation proceeded (Fig. 2). However, in the case of strains WE 452 and WE 500 the SFA concentrations decreased considerably from the first to the second fermentation stage, whereafter they increased. The final SFA concentrations of the latter two strains were considerably higher than those of WE 14 and WE 372 (Table 2).

\section{TABLE 1}

Mean unsaturated fatty acid concentration in four yeast strains at three temperatures during the sixth fermentation stage.

\begin{tabular}{|c|c|c|c|c|}
\hline \multirow{2}{*}{$\begin{array}{c}\text { Temp. } \\
\left({ }^{\circ} \mathrm{C}\right)\end{array}$} & \multicolumn{3}{|c|}{ Unsaturated fatty acid concentration (mg/100 mg) } \\
\cline { 2 - 5 } & WE 452 & WE 500 & WE 14 & WE 372 \\
\hline 10 & $0,91 \mathrm{~b}$ & $1,51 \mathrm{a}$ & $1,07 \mathrm{a}$ & $0,98 \mathrm{~b}$ \\
15 & $0,89 \mathrm{~b}$ & $0,85 \mathrm{~b}$ & $0,98 \mathrm{~b}$ & $0,75 \mathrm{~b}$ \\
20 & $0,68 \mathrm{~b}$ & $0,69 \mathrm{~b}$ & $0,61 \mathrm{~b}$ & $0,84 \mathrm{~b}$ \\
\hline
\end{tabular}

Means, within rows, followed by the same letter do not differ significantly $(\mathrm{P} \leq 0,05)$ 

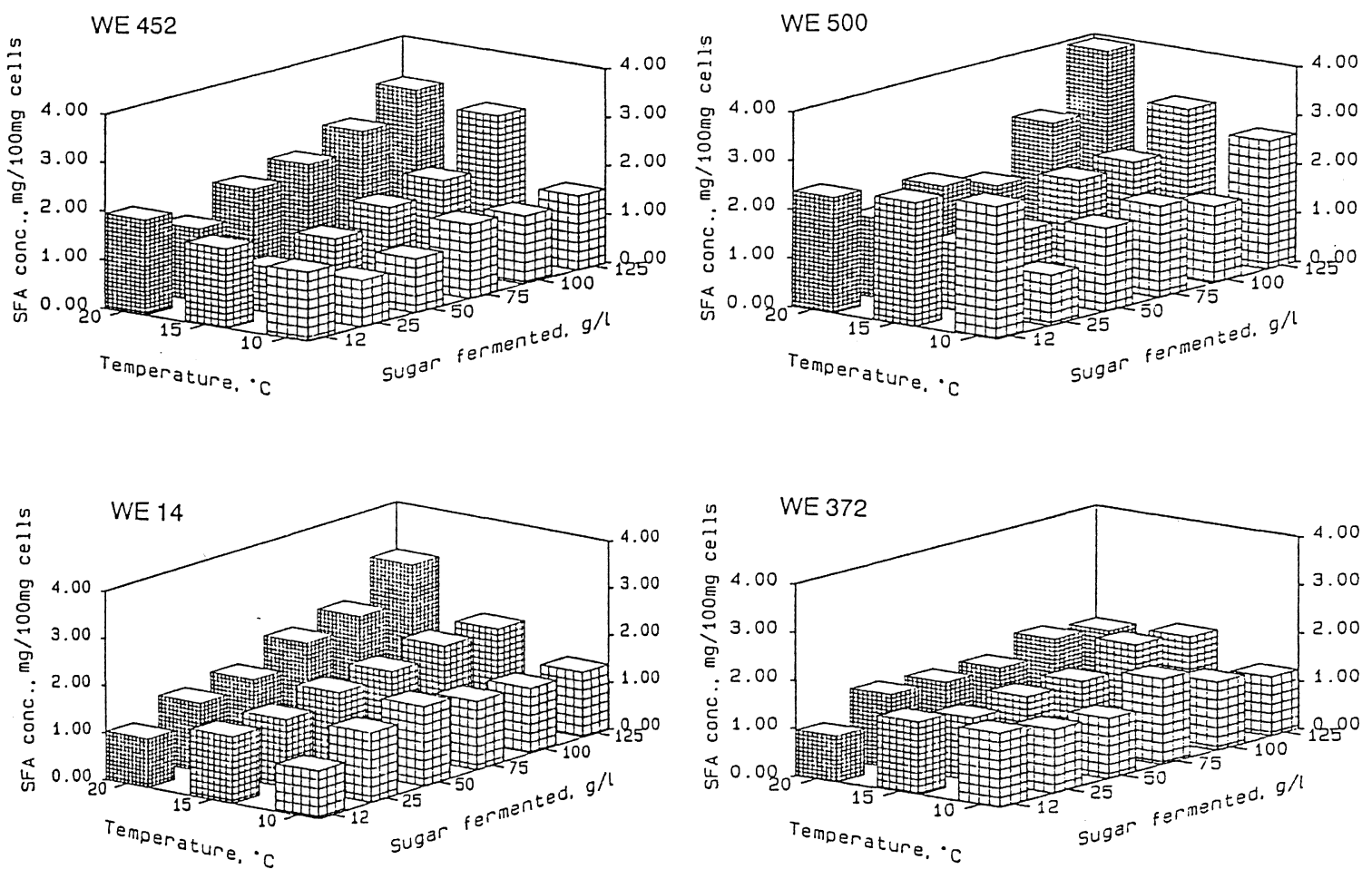

FIGURE 2

Saturated fatty acid concentration in cells of Saccharomyces cerevisiae strains WE 452, WE 500, WE 14 and WE 372 during fermentation at three temperatures.

When the SFA concentrations shown in Fig. 2 were compared with the SFR values of Venter et al. (1989), it was found that the former did not affect the latter during fermentation. However, at the final stage a positive correlation $(r=0,87)$ was found between the SFA concentrations and SFR of the four yeast strains. These results confirmed those of Nagar-Legmann \& Margalith (1987) who showed that a fast-fermenting strain of Sacch. cerevisiae had higher SFA and free sterol concentrations than Sacch. mellis T 453 [reclassified as Zygo- saccharomyces cerevisiae (Von Arx, 1978)], which was a slow fermentor. Otoguro et al. (1981) indicated that the membranes of Sacch. cerevisiae require certain amounts of SFA and that membrane functions (energy metabolism, transport, etc.) are impaired by SFA starvation. The importance of SFA in the membrane should therefore not be underestimated.

Furthermore, it was obvious that higher saturation index (SI) values were generally obtained at the higher temperatures and these values generally increased further as the fermenta-

\section{TABLE 2}

Mean saturated fatty acid concentration in four yeast strains at three temperatures during the sixth fermentation stage.

\begin{tabular}{|c|c|c|c|c|}
\hline \multirow{2}{*}{$\begin{array}{c}\text { Temp. } \\
\left({ }^{\circ} \mathrm{C}\right)\end{array}$} & \multicolumn{4}{|c|}{ Saturated fatty acid concentration (mg/100 mg) } \\
\cline { 2 - 5 } & WE 452 & WE 500 & WE 14 & WE 372 \\
\hline 10 & $1,52 \mathrm{ab}$ & $2,62 \mathrm{a}$ & $1,23 \mathrm{~b}$ & $1,38 \mathrm{ab}$ \\
15 & $2,90 \mathrm{a}$ & $3,00 \mathrm{a}$ & $2,97 \mathrm{a}$ & $1,96 \mathrm{a}$ \\
20 & $3,16 \mathrm{a}$ & $3,92 \mathrm{a}$ & $1,43 \mathrm{~b}$ \\
\hline
\end{tabular}

Means, within rows, followed by the same letter do not differ significantly $(\mathrm{P} \leq 0,05)$ 
TABLE 3

The mean saturation index for four yeast strains at six fermentation stages at three temperatures.

\begin{tabular}{|c|c|c|c|c|c|c|c|c|c|c|c|c|}
\hline \multirow{3}{*}{$\begin{array}{c}\text { Sugar } \\
\text { fermented } \\
(\mathrm{g} / \mathrm{l})\end{array}$} & \multicolumn{12}{|c|}{ Mean saturation index ${ }^{a}$} \\
\hline & \multicolumn{3}{|c|}{ WE 452} & \multicolumn{3}{|c|}{ WE 500} & \multicolumn{3}{|c|}{ WE 14} & \multicolumn{3}{|c|}{ WE 372} \\
\hline & $10^{\circ} \mathrm{C}$ & $15^{\circ} \mathrm{C}$ & $20^{\circ} \mathrm{C}$ & $10^{\circ} \mathrm{C}$ & $15^{\circ} \mathrm{C}$ & $20^{\circ} \mathrm{C}$ & $10^{\circ} \mathrm{C}$ & $15^{\circ} \mathrm{C}$ & $20^{\circ} \mathrm{C}$ & $10^{\circ} \mathrm{C}$ & $15^{\circ} \mathrm{C}$ & $20^{\circ} \mathrm{C}$ \\
\hline 12 & 0,88 & 1,16 & 1,20 & 1,31 & 1,23 & 1,40 & 0,77 & 0,99 & 0,88 & 0,84 & 0,95 & 0,92 \\
\hline 25 & 0,80 & 1,36 & 1,00 & 0,89 & 1,01 & 1,52 & 0,85 & 0,94 & 1,51 & 1,26 & 1,19 & 1,60 \\
\hline 50 & 0,99 & 1,42 & 2,05 & 1,27 & 1,45 & 1,92 & 1,01 & 1,14 & 1,94 & 1,51 & 1,56 & 1,72 \\
\hline 75 & 1,32 & 1,95 & 2,88 & 1,50 & 2,52 & 2,12 & 1,25 & 1,50 & 1,83 & 1,48 & 2,01 & 2,39 \\
\hline 100 & 1,35 & 2,16 & 3,68 & 1,40 & 2,32 & 3,86 & 1,20 & 1,60 & 2,80 & 1,41 & 2,35 & 3,03 \\
\hline 125 & 1,67 & 3,26 & 4,65 & 1,73 & 3,49 & 5,68 & 1,15 & 2,02 & 2,30 & 1,41 & 2,61 & 4,04 \\
\hline
\end{tabular}

\section{${ }^{\mathrm{a}}$ Mean saturation index $=\quad$ Unsaturated fatty acid conc.}

tion progressed (Table 3). It also appeared as if the cell membranes of yeast strains WE 452 and WE 500 at the sixth stage were less fluid (relatively higher SFA concentrations) than the membranes of strains WE 14 and WE 372.

Our results suggest that high membrane fluidity is incompatible with high SFR during the later stages of fermentation. It has been suggested that high membrane fluidity may be involved in the entrapment of ethanol molecules within the hydrophobic area of the membrane, interfering with its free movement out of the cell (Legmann \& Margalith, 1986).

At the sixth fermentation stage the yeast cells contained relatively low concentrations of ergosterol (Venter et al., 1989) and UFA (Fig. 1). Watson \& Rose (1980) postulated a mechanism whereby membrane fluidity could be balanced through synthesis of phosphatidylinositol and phosphatidylserine containing a higher proportion of saturated fatty-acyl residues, strategically located in the membrane and thereby maintaining a degree of rigidity $\mathrm{n}$ that domain.

\section{CONCLUSIONS}

Fermentation temperatures affected the fermentation rate, UFA and SFA concentrations of different yeast strains to a great extent. High specific fermentation rates at the later stages of fermentation were correlated with high SFA concentrations. It appears to be in contrast with the findings of other workers i.e. that fluid membranes containing relatively high concentrations of UFA, might interfere with the movement of ethanol out of the yeast cell. A high intracellular concentration of ethanol will impair fermentation capabilities of yeast. On the other hand, results from this study in synthetic media indicate that high concentrations of SFA might well render yeast cells more tolerant to ethanol than their unsaturated counterparts, enhancing fermentation rates in the presence of ethanol during the later stages of fermentation.

\section{LITERATURE CITED}

ANDREASEN, A.A., \& STIER, T.J.B., 1954. Anaerobic nutrition of Saccharomyces cerevisiae. II. Unsaturated fatty acid requirement for growth in a defined medium. J. Cell. Comp. Physiol. 43, 271-281.

ANONYMOUS, 1985. SAS User's Guide: Statistics, 1985. Version 5 Edition, SAS Institut Inc., Cary, NC.

BLOCH, K. BARONOWSKY, P., GOLDFINE, H., LENNARZ, W.J., LIGHT, R., NORRIS, A.T. \& SCHEUERBRANDT, G., 1961. Biosynthesis and metabolism of unsaturated fatty acids. Fed. Proc. Fed. Am. Soc. Exp. Biol. 20, 961-973.

BROWN, C.M. \& ROSE, A.H., 1969a. Effects of temperature on composition and cell volume of Candida utilis. J. Bacteriol. 97, 261-272.

BROWN, C.M. \& ROSE, A.H., 1969b. Fatty acid composition of Candida utilis as affected by growth temperature and dissolved-oxygen tension. J. Bacteriol. 99, 371-378.

JOHNSON, B.S., NELSON, C.J. \& BROWN, C.M., 1972. Influence of glucose concentration on the physiology and lipid composition of some yeasts. Antonie van Leeuwenhoek, J. Microbiol. 38, 129-136.

LEGMANN, R. \& MARGALITH, P., 1986. Ethanol formation by hybrid yeasts. Eur.J. Appl. Microbiol. Biotechnol. 23, 198-202.

McMURROUGH, I. \& ROSE, A.H., 1971. Effects of temperature variation on the fatty acid composition of Candida utilis. J. Bacteriol. 107, 753-758.

MOSS, C.W., SHINODA, T. \& SAMUELS, J.W., 1982. Determination of cellular fatty acid compositions of various yeasts by gas-liquid chromatography. J. Clin. Microbiol. 16, 1073-1079.

NAGAR-LEGMANN, R. \& MARGALITH, P., 1987. A comparative study of the lipid composition of yeasts with different fermentative capacities. Eur.J.Appl. Microbiol. Biotechnol. 26, 49-54.

OTOGURO, K., AWAYA, J., TANAKA, H. \& OMURA, S., 1981. Saturated fatty acidstarved cells of Saccharomyces cerevisiae grown in the presence of cerulenin and oleic acid. J. Biochem. 89, 523-529.

PATEL, P.C. \& LEWIS, M.J., 1982. Influence of growth temperature on the fatty acid composition of the cytoplasmic membrane of a larger yeast. J. Am. Soc. Brew. Chem. 40, 26-30.

PFISTERER, E., HANCOCK, I. \& GARRISON, I., 1977. Effects of fermentation environments on yeast lipid synthesis. J. Am. Soc. Brew. Chem. 35, 49-54.

RADLER, F., 1978. Promotors of the yeast anaerobic growth. Ann. Technol. Agric. 27, 203-213.

RATTRAY, J.B.M., SCHIBECI, A. \& KIDBY, D.K., 1975. Lipids of yeasts. Bacteriol. Rev. 39, 197-231.

SINENSKY, M., 1971. Temperature control of phospholipid biosynthesis in Escherichia coli.J. Bacteriol. 106, 229-455.

THOMAS, D.S., HOSSACK, J.A. \& ROSE, A.H., 1978. Plasma-membrane lipid composition and ethanol tolerance in Saccharomyces cerevisiae. Arch. Microbiol. 117, 239-245.

VON ARX, J.A., 1978. Centraalbureau voor Schimmelcultures. Progress Report 1977. Verh. Kon. Ned. Akad. Wetensch., Afd. Natuurk., 2e Reeks, 71, 175-195.

VENTER, J.J., VAN VUUREN, H.J.J., TROMP, A. \& RANDALL, J.H., 1989. Relationship between ergosterol concentration in wine yeasts and sugar fermentation at different temperatures $S$. Afr. J. Enol. Vitic. 10, 36-43.

WATSON, K. \& ROSE, A.H., 1980. Fatty-acyl composition of the lipids of Saccharomyces cerevisiae grown aerobically or anaerobically in media containing different fatty acids. J. Gen. Microbiol. 117, 225-233. 